Ann. Biol. anim. Bioch. Biophys., 1979, 19 (2 B), 471-477.

\title{
Avant-propos : la sélection du colza sans acide érucique
}

par J. MORICE

Station d'Amélioration des Plantes, I.N.R.A., Domaine de la Motte au Vicomte, B. P. 29 35650 Le Rheu.

La publication des résultats de recherches sur les caractéristiques nutritionnelles de l'huile de colza est particulièrement intéressante au moment où l'agriculture et l'industrie françaises mettent à la disposition du consommateur un produit reconnu nouveau par la législation qui le dénomme " Nouvelle Huile de Colza ».

C'est l'aboutissement des études génétiques et des travaux de sélection réalisés pour créer des variétés de colza donnant une huile dépourvue des acides gras monoinsaturés à longue chaîne qui la caractérisent normalement : acide éicosénoïque et surtout acide érucique. Ces recherches furent engagées il y a une douzaine d'années. A cette époque certains spécialistes de la nutrition pouvaient s'interroger sur la qualité nutritionnelles de l'huile de colza à la suite de quelques expériences sur diverses espèces animales sans que leurs critiques atteignent dans leur fond et dans leur forme les excès que l'on a connus depuis. Les acides gras monoinsaturés à longue chaîne caractéristiques de l'huile de colza étant rendus responsables des effets physiopathologiques observés, nous avons entrepris en France, comme dans d'autres pays producteurs de colza (le Canada, la Suède, l'Allemagne, la Pologne), la mise en œurre d'une solution génétique à ce problème.

Les généticiens canadiens, ayant les premiers abordé cefte recherche, avaient trouvé, par une large prospection, des plantes donnant une huile pratiquement sans acide érucique. Ce fut l'origine de la sélection de leurs diverses variétés dénommées sous le terme général de Canbra qui regroupe à la fois des variétés de colza de printemps (Brassica napus L.) et de navette de printemps (Brassica campestris L.).

Ces variétés ne sont pas adaptées à nos conditions. On cultive principalement en France du colza d'hiver et la sélection entreprise sur l'espèce, depuis la dernière guerre, conduit dans les années 60 à l'obtention de variétés productives, riches en huile, résistantes au froid, résistantes à la verse et dans lesquelles on venait d'incorporer la résistance à une très grave maladie du colza, le Phoma lingam. En face de ces caractéristiques accumulées par plusieurs cycles de sélection, les types Canadiens, notamment les plantes de départ, présentent de graves défauts agronomiques. Le colza Canbra constitue donc un géniteur remarquable par la composition de son huile mais il faut, dans le programme de sélection mis en œuvre, n'introduire que ce caractère dans nos meilleures variétés et lignées de colza d'hiver. Il faut aussi accélérer la 
réalisation de ce programme : d'une part, évidemment, au plan nutritionnel, it semble utile d'éliminer l'acide érucique ; d'autre part, même si le problème de l'acide érucique n'est pas d'une gravité extrême pour la santé humaine, le producteur français de colza risque d'être défavorisé si d'autres pays proposent sur le marché international des colzas avec comme argument commercial l'absence d'acide érucique.

Les études génétiques montrent que le déterminisme héréditaire de la teneur en acide érucique de l'huile de colza est relativement simple. Deux gènes majeurs interviennent : le génotype double homozygote récessif ne présente que des traces d'acide érucique $(<0,5$ p. 100) et très peu d'acide éicosénoïque (de l'ordre de 1 p. 100) ; le génotype normal, double homozygote dominant, donne une huile contenant, par rapport au total des acides gras, environ 50 p. 100 d'acide érucique et 10 p. 100 d'acide éicosénoïque. Et les génotypes intermédiaires ont aussi des compositions d'huile intermédiaires, avec des teneurs en acide érucique qui varient en fonction du nombre d'allèles dominants qu'ils possèdent.

La biosynthèse des acides gras est contrôlée au niveau de la graine de colza qui est presque entièrement remplie par les deux colylédons de l'embryon. La présence ef la quantité d'enzymes responsables de l'allongement de la chaîne carbonée dépendent donc du génotype de chaque embryon. Sur une plante hétérozygote donnant une population d'embryons en disjonction, chaque graine présente une composition particulière. Eł malgré l'erreur et la variation non contrôlée qui entourent les résultats d'analyse individuelle, il est possible de regrouper les graines par classes, qui correspondent à différents génotypes, en fonction de teneur en acide érucique de leur huile.

L'ensemble de ces considérations nous a conduit, après des hybridations de départ entre le colza de type Canbra et des lignées de colza d'hiver, a réaliser des rétrocroisements successifs par celles-ci. Au cours de ce programme, on trie à chaque génération, parmi les graines issues du rétrocroisement, celles qui ont conservé les deux gènes récessifs canadiens à l'état hétérozygote. Cette sélection s'opère d'après les analyses de composition d'huile effectuées sur un cotylédon de chaque graine (environ $1 \mathrm{mg}$ de matière sèche). Lorsque la teneur en acide érucique de l'huile extraite du cotylédon révèle que la graine présente le génotype recherché, la plantule correspondante, qui reste viable malgré l'amputation, est conservée et utilisée pour la génération suivante de sélection.

Ainsi, les générations de recroisements, au cours desquelles des recombinaisons s'opèrent au sein des génotypes hétérozygote, conduisent progressivement à l'élimination des caractéristiques portées par le géniteur Canadien à l'exception des gènes conditionnant l'absence d'acide érucique. En fin de programme, une simple autofécondation restitue la forme sans acide érucique de la variété utilisée comme parent récurrent des rétrocroisements.

L'accélération de la sélection est obtenue par la culture en serres avec éclairement supplémentaire pendant l'hiver (le colza est une plante de jour long) et par le passage des jeunes plantes en chambres froides pendant plusieurs semaines (le colza d'hiver a besoin de vernalisation pour fleurir). On peut en jouant sur les conditions de température et d'éclairement, obtenir deux générations par an alors que, dans les conditions naturelles, le colza d'hiver met environ 10 mois pour boucler son cycle végétatif.

Le premier résulfat de cette sélection a été l'obtention de la variété Primor qui 
représente la version sans acide érucique de la variété normal Major. A partir de 200 graines sans acide érucique, sélectionnées individuellement en 1970 dans un ensemble d'environ 3500 graines, une multiplication est engagée pour la production des semences de ce nouveau colza. Grâce au coefficient de multiplication très élevé du colza, 3 ans plus tard, en 1973, on peut fournir environ 2000 tonnes de semences de Primor dont on a aussi pu tester les caractéristiques culturales par une large expérimentation. En moyenne, et cela a été confirmé par les très nombreux essais des années ultérieures, le rendement de Primor était très légèrement inférieur, d'environ 5 p. 100 , à celui de la variété Major, la meilleure variété de l'époque. Ce résultat pouvait être considéré comme satisfaisant et ce prototype de variété de colza d'hiver sans acide érucique a été largement cultivé pendant quelques années en attendant qu'un deuxième cycle de sélection en améliore la productivité.

Au plan de la composition de l'huile on avait transposé dans un colza d'hiver les caractéristiques de Canbra (voir tableau).

Composition comparée des huiles de Major et de Primor

(Acides gras en p. 100 du total)

\begin{tabular}{|c|c|c|c|}
\hline & Acides gras & Major & Primor \\
\hline $\begin{array}{l}\text { - Palmitique } \\
\text { - Palmitoléique } \\
\text { - Stéarique } \\
\text { - Oléique } \\
\text { - Linoléique } \\
\text { - Linoléique } \\
\text { - Eicosénoïque } \\
\text { - Erucique }\end{array}$ & 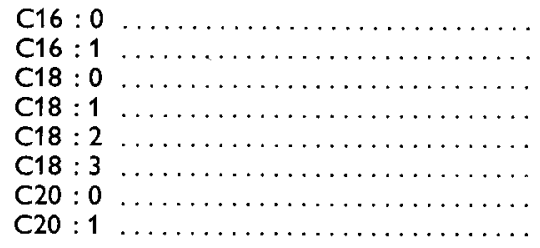 & $\begin{array}{r}3,5 \\
0,4 \\
1,2 \\
14,2 \\
13,8 \\
9,1 \\
10,9 \\
46,9\end{array}$ & $\begin{array}{r}4,5 \\
0,6 \\
1,5 \\
60,5 \\
21,5 \\
10,3 \\
0,9 \\
0,3\end{array}$ \\
\hline
\end{tabular}

La variété Primor a été cultivée pendant quatre ans et les variétés traditionnelles ont progressivement disparu. Elle a été, elle-même, remplacée presque complètement en 1977 par une variété française plus productive d'environ 20 p. 100, Jet neuf. Ainsi, après une période de stagnation de la productivité du colza en France, due au temps nécessaire pour créer le premier colza d'hiver sans acide érucique à partir d'une variété normale, le progrès génétique se trouve maintenant relancé.

La conversion assez remarquable réalisée rapidement au niveau d'une production d'environ 300000 hectares a pu être effectuée grâce à l'action efficace des organisations techniques et professionnelles qui s'intéressent aux oléagineux ef qui ont organisé et réalisé l'expérimentation à grande échelle, l'information des producteurs, la production des semences, la collecte du nouveau colza...

Maintenant, malgré quelques cultures de colza normal qui peuvent subsister dans diverses régions, malgré les repousses de colza qui, après plusieurs années peuvent contaminer de nouvelles cultures, la teneur moyenne en acide érucique de la producfion française se situe en dessous de 5 p. 100. Et elle doit tendre progressivement vers la teneur très faible $(<0,5$ p. 100) de toutes les variétés sélectionnées actuellement, de colza d'hiver et de colza de printemps, ce dernier ne représentant que moins de 10 p. 100 de la production. 
L'élimination de l'acide érucique ne constitue que l'un des objectifs de l'amélioration de colza. On peut considérer que cel objectif est atteint. En France, la sélection du colza, publique et privée, poursuit d'autres buts qui touchent à la productivité et à la qualité des produits. On voit dans le colza une plante qui, à l'avenir, pourrait de plus en plus concurrencer le soja, aussi bien par son huile que par son tourteau. Les recherches sont engagées pour faire progresser sensiblement les rendements par la mise en œuvre de méthodes de sélection nouvelles et pour conférer à la plante le maximum de facteurs de résistance aux maladies qui l'altaquent. Elles visent à valoriser ses protéines en éliminant, par la voie génétique, les facteurs antinutritionnels que constituent les glucosinolates. Et, au plan de l'huile, elles cherchent un meilleur rapport entre les acides gras insaturés. Il semble en effet désirable, essentiellement pour les propriétés organoleptiques de l'huile, surtout quand elle est chauffée, de réduire la teneur en acide linolénique. Pour cette caractéristique, les recherches sont engagées dans deux voies pour augmenter la variabilité génétique de l'espèce : croisements interspécifiques, mutagénèse provoquée.

Les éfudes génétiques et les programmes de sélection sont toujours assez lourds à conduire, réclament des moyens importants, mobilisent chercheurs et techniciens. Avant de les engager dans une direction, ef c'est particulièrement important pour les problèmes de qualité, il est indispensable que les objectifs soient bien précisés par les chercheurs des autres disciplines qui ont compétence pour le faire. Il est certainement satisfaisant pour un généticien de constater que le produit nouveau qu'il a contribué à créer apporte quelqu'amélioration nutritionnelle par rapport au produit initial. Mais il est surtout important que les scientifiques qui étudient les effets physiopathologiques et les caractéristiques nutritionnelles lui fassent connaître nettement les substances indésirables et les seuils que l'on peut tolérer. Dans le cas des huiles, il semble que le bilan global de l'élimination des acides gras monoinsaturés à longue chaîne soit bénéfique. De toutes ces études réalisées parce qu'à un moment on a mis en accusation l'huile de colza, on peut certainement tirer d'auires conclusions, qui auront besoin de s'étayer sur de nouvelles recherches. Elles peuvent notamment concerner les rapports entre acides gras saturés et insaturés et l'importance du niveau d'insaturation. Le sélectionneur de plante oléagineuse, et de colza en particulier, va suivre avec intérêt l'évolution des idées dans ce domaine avec l'intention d'exploiter, dans le sens jugé bon, la variabilité qu'il peut trouver ou créer dans l'espèce végétale. Mais son ambition ne peut aller jusqu'à vouloir obtenir de la plante l'huile idéale. Celle-ci n'existe d'ailleurs pas, ni pour la variété des consommateurs ni dans les conceptions variées des spécialistes de la nutrition des lipides. Les solutions que le généticien peut mettre en œuvre doivent essentiellement corriger les graves défauts, rétablir les grands équilibres. Les ajustements se font ensuite dans la variété des corps gras utilisés dans l'alimentation humaine et les industries de l'huilerie peuvent en fonction de recommandations d'ordre technologique ou d'ordre nutritionnel utiliser la gamme desoléagineux dont ils disposent pour réaliser des mélanges où les acides gras seraient mieux équilibrés que dans une seule huile. 


\section{Foreword : The selection of erucic acid-free rapeseed}

The publication of research results on the nutritional characteristics of rapeseed oil is particularly timely at the moment when French agriculture and industry are making available to consumers a new product recognized by law as " the new rapeseed oil $\gg$.

This new oil is the end result of genetic studies and selection attempting to create rapeseed varieties giving an oil free of the long-chain mono-unsaturated fatty acids (eicosenoic acid and particularly erucic acid) which normally characterize it. Research on the oil began about 12 years ago; at that time, some specialists in nutrition, carrying out experiments on various animal species, could question the nutritive qualities of rapeseed oil without reaching the excessive criticism of it which we have witnessed since then. Because the long-chain monounsaturated fatty acids characterizing rapeseed oil were held responsible for the physiopathological effects observed, French research undertook a genetic solution to the problem, as did other countries producing rapeseed (Canada, Sweden, Germany, Poland).

Canadian geneticists were the first to tackle this problem. After wide prospection, they found plants giving an almost erucic acid-free oil, and began selecting their different varieties which were grouped under the general term of Canbra. This term includes both the varieties of spring rapeseed (Brassica napus L.) and of spring turnip rapeseed (Brassica campestris L.).

These varieties are not adapted to our conditions in France where winter rapeseed is principally grown. Selection of the latter species since the last war led, in the 1960's, to the obtention of productive varieties which were rich in oil, resistant to cold and to lodging, and had just been made resistant to a very serious rapeseed disease, Phoma lingam. As compared to the characteristics accumulated by several cycles of selection, the Canadian types, especially the original ones, have serious agronomical defects. Canbra rapeseed is thus a remarkable parent because of its oil composition but, in the selection program used, only this characteristic can be introduced into our best varieties and lines of winter rapeseed. This program must also be accelerated because, on one hand, it seems necessary to eliminate erucic acids for human consumption and, on the other hand, even if the question of erucic acid is not an extremely serious one for human health, the French rapeseed producer may be defavorized if other countries propose to put on the market erucic acid-free rapeseed, using this quality as a commercial argument.

Genetics studies show that the hereditary determinism of erucic acid in rapeseed oil is relatively simple. Two major genes are implicated :

The homozygous recessive genotype shows only traces of erucic acid $(<0.5$ p. 100) and very little eicosenoic acid (about 1 p. 100) ;

The normal homozygous dominant genotype gives an oil in which erucic acid and eicosenoic acid form 50 p. 100 and 10 p. 100, respectively, of the total fatty acid content. Intermediate genotypes also have intermediate oil compositions in which erucic acid levels vary with the number of dominant alleles they possess.

Fatty acid biosynthesis is controlled in the rapeseed seed which is almost entirely filled by the two cotyledons of the embryo. The presence and quantity of the enzymes 
causing the carbonaceous chain to lengthen thus depend on the genotype of each embryo. On a heterozygous plant giving a discrete embryonic population, each seed has a particular composition. In spite of the uncontrolled error and variation surrounding the results of individual analysis, the seeds can ben divided into classes corresponding to different genotypes, depending on the erucic acid content of their oil.

Considering all these facts, it was decided, after some initial hybridizations between Canbra rapeseed and winter rapeseed, to carry out backcrosses with the hybrids. This program provides that those seeds which have retained the two heterozygous recessive Canadian genes are to be selected from among the seeds of the backcross at each generation. This selection is made after analyses of the oil composition of one cotyledon from each seed (about $1 \mathrm{mg}$ of dry matter). When the level of erucic acid in the oil extracted from the cotyledon shows that the seed has the desired genotype, the corresponding plantlet, which remains alive in spite of amputation, is stored and used in the following selection generation.

Thus, backcrossing generations, during which recombinations occur within the heterozygous genotypes, gradually lead to elimination of the characteristics carried by the Canadian parent, except for the genes controlling the absence of erucic acid. At the end of the program, simple self-fertilization restores the erucic acid-free form of the variety used as the recurring parent of the backcrosses.

Selection is accelerated by green house cultivation with supplementary lighting in winter (rapeseed is a long-day plant) an by storing the young plants in cold rooms several weeks (winter rapeseed needs vernalization in order to flower). By taking advantage of these conditions of temperature and lighting, two generations per year may be obtained, while in natural conditions the vegetative cycle of winter rapeseed requires about 10 months.

The Primor variety, the erucic acid-free version of the normal Major variety, was the first result of this selection. 200 erucic acid-free seeds, individually selected in 1970 from 3500 seeds, were used to multiply the seed production of this new rapeseed. Due to the very high multiplication rate of rapeseed, about 2000 tons of Primor seeds were produced 3 years later in 1973 ; their growth characteristics were tested by wide experimentation. As confirmed by many later trials, the mean yield of Primor was slightly less than 5 p. 100 of that of the Major variety which was the best variety at that time. The result was considered satisfactory and this prototype winter rapeseed variety, free of erucic acid, has been widely grown for several years while waiting for a second selection cycle to improve productivity.

As regards oil composition, the characteristics of Canbra had been transposed into a winter rapeseed (see table).

During the 4 years that the Primor variety has been grown, the traditional varieties have gradually disappeared. The Primor variety itself almost completely replaced in 1977 by a French variety (Jet neuf) which is about 20 p. 100 more productive. Thus, genetic progress in rapeseed productivity has recently been been given a new impetus in France after a period of stagnation during the time needed to create the erucic acidfree rapeseed from a normal variety.

The remarkable, rapid conversion of about 300000 hectares was achieved owing to the efficiency of technical and professional organizations interested in oils which 
organized and conducted large-scale experiments, producer counselling, seed production and the marketing of the new rapeseed.

Now, in spite of some normal rapeseed crops in various regions, and in spite of regrowths of rapeseed which, after several years, may contaminate the new cultures, the mean erucic acid content of French rapeseed production is less than 5 p. 100, and it should gradually tend towards the very low content $(<0.5$ p. 100) of all the varieties of the winter and the spring rapeseed actually selected, the latter only representing less than 10 p. 100 of the production.

The elimination of erucic acid is only one of the aims of rapeseed improvement, and this objective has been achieved. Public and private selection of rapeseed in France has other goals related to product productivity and quality. Rapeseed is regarded as a plant of the future which could progressively compete with soya oil and oil meals. Research is underway to significantly increase yield by new methods of selection and to incorporate into the plant maximum factors of resistance to the diseases which attack it. This research aims at valorizing rapeseed proteins by genetically eliminating the glucosinolates which are anti-nutritional factors. As concerns the oil, research scientists are trying to define a better ratio of its unsaturated fatty acids.

To improve the organoleptic properties of rapeseed oil when it is heated, it would be desirable to reduce the linolenic acid level. To this end, two types of research are being undertaken to increase the genetic variability of the species : interspecific crossing and induced mutagenesis.

Genetic studies and selection programs are always rather costly, demanding important means and mobilizing research scientists and technicians. Before committing them to a course of action - and this is particularly important for problems of quality - research aims must be well defined by competent scientists of other disciplines. There is no doubt that it is satisfying to a geneticist to see that the new product he has contributed to create is a nutritional improvement over the original one. However, it is especially important that the scientists who study physiopathological effects and nutritional characteristics enlighten him clearly as to undesirable substances and thresholds of toleration. In the case of oils, the consensus of opinion seems to be that the elimination of long-chain monounsaturated fatty acids is beneficial. Other conclusions can also certainly be drawn from all the work on the accused rapeseed oil, and they must be confirmed by new research. This research may concern the ratios between saturated and unsaturated fatty acids and the importance of the level of unsaturation. The oilseed plant breeder, and particularly the rapeseed breeder, will follow with interest the progression of ideas in this field with the intention of exploiting, in the good sense, the variability which he finds or creates in the plant species. However, he cannot think to find the ideal oilseed plant because it does not exist, either as a variety for human consumption or in the varied concepts of specialists in lipid nutrition. The solutions which the geneticist has at his disposal should correct the serious defects of the plant and restore its principal balances. Adjustments are then made in the varieties of the fatty matter used in human foods, and the oilseed industry, working with the technologial or nutritional recommendations obtained from research, may use the range of oilseeds available to produce mixtures having a better fatty acid balance than a single oil. 